\title{
The long noncoding RNA-30162 is regulated by commensal microbiota and modulates CCL24 and ARG1 in macrophages
}

\section{Yingjie Mu}

Anhui Medical University https://orcid.org/0000-0002-0773-8257

\section{Wen Chen}

Anhui Medical University

Shilian Hu ( $D$ hushilian@126.com )

Min Cheng

Anhui Medical University

\section{Research article}

Keywords: commensal microbiota, alveolar macrophages, IncRNA-30162, CCL24, ARG1

Posted Date: January 8th, 2020

DOI: https://doi.org/10.21203/rs.2.20362/v1

License: (a) (i) This work is licensed under a Creative Commons Attribution 4.0 International License. Read Full License 


\section{Abstract}

\section{Background}

Alveolar macrophages (AMs) are the largest number of innate immune cells in the distal lung. AMs have critical roles in maintaining immunological homoeostasis and host defense in the lung and are inherently suppressive. Immune homeostasis depends on the integrity of microbiome, which contribute to appropriate maturation and priming of the immune system. The absence of commensal microbiota can lead to changes in AM function; however, little is known about the effect of long non-coding RNA (IncRNA) molecules in this process.

\section{Results}

Here, by IncRNA microarray analysis using AM samples from antibiotic-treated (Abt) mice, we found that treatment with antibiotics resulted in differential expression of numerous IncRNAs in AMs. Target genes of differentially expressed IncRNAs were associated with several biological pathways, including regulation of immune system processes, angiogenesis, cell differentiation, and chemotaxis, among others. Notably, IncRNA-30162 expression levels were up-regulated in AMs from Abt mice. Moreover, knockdown of IncRNA30162 expression significantly reduced CCL24 and ARG1 levels in macrophages.

\section{Conclusions}

These findings indicate that microbiome can regulate the expression of IncRNA-30162 in AMs, identifying a molecular mechanism underlying IncRNA-mediated regulation of macrophage functions.

\section{Background}

The respiratory tract is a complex mucosal tissue. There are specific commensal microbiota from the nostrils to the lung alveoli (upper respiratory tract and lower respiratory tract) that are regarded as "gatekeepers" of respiratory tract health and play crucial roles in the development of organs and maintenance of immune homeostasis [1]. In the past, researchers considered it established that the lung was sterile; however, with the development of advanced sequencing technology, in vitro culture technology, and bioinformatics, it has been proven that lung tissue contains specific commensal microbiota, primarily Proteobacteria and Firmicutes, like the upper respiratory tract,but community richness of upper respiratory tract was higher than low respiratory tract [2]. Compared with the upper respiratory tract, the lung has low numbers of bacteria; however, small changes in the number or composition of its microbiota can have dramatic effects on host responses to inflammation [3]. There is a clear interplay between the lungs and the intestines. Intestines microbiome protects the lungs from bacterial and viral infections by regulating immune responses. Varieties of lung disorders are strongly linked to dysbiosis of the gut mycobiota. Chronic gastrointestinal diseases have a higher incidence of lung diseases, such as inflammatory bowel disease and irritable bowel syndrome [4, 5]. 
Alveolar macrophages (AMs), situated on the surface of alveolar cavities, are the richest innate immune cells in the distal lung. These cells are critical for maintenance of immunological homoeostasis, and host defenses in the lung and are inherently suppressive [6-8]. The function of AMs is strongly influenced by the commensal microbiota, by inducing bacterial killing by AMs, the microbiome enhances early innate immune system defenses against bacterial infection [9]. Also, the commensal microbiota promote bacterial clearance from the lung by stimulating AMs to produce antibacterial activity [10]. In lung ischemia reperfusion, commensal microbiota prime the inflammatory response by inducing cytokine production by AMs [11]. In 2017, we reported that commensal microbiota maintain AM CCL24 production at low levels, thereby generating anti-metastatic tumor activity [12]. Nevertheless, the molecular mechanisms by which commensal microbiota exert their immune-modulating effects on AMs remain unknown.

Long noncoding RNAs (IncRNAs) refer to a genome without protein-coding function, and which more than 200 nucleotides [13]. These molecules contribute to cellular responses, including gene expression involved in epigenetic and cell function control, promotion of hematopoiesis, immune maturation, modulation of pathogen infection, and initiation of autoimmune diseases [14]. Commensal microbiota can influence IncRNA expression, with levels of IncRNAs in heart, hippocampus, liver, lung, spleen, and thymus of conventional and gnotobiotic mice differing significantly from those of germ-free (GF) mice, suggesting that IncRNAs probably associated with microbiome. Furthermore, various microbiota can induce differential expression of IncRNAs [15]. The intestinal microbiota can regulate the expression of IncRNAs in the gut and other metabolic organs, such as fat, muscle, and liver, [16]. Recent studies have identified some IncRNAs associated with macrophages. Further, the IncRNA, E33, regulates proinflammatory gene expression in macrophages [17], while the expression of inflammatory cytokines by macrophages is negatively regulated by the IncRNA, Malat2, to suppress inflammation [18]. The IncRNA-CCL2, regulates macrophage expression of IL-1 $\beta$, IL-6, and TNF-a [19]. Further, in pulmonary fibrosis, the IncRNA, Malat1, is a negative regulator of $\mathrm{M} 2$ macrophage polarization, and regulates the profibrotic phenotype of macrophages [20]. Therefore, we hypothesized that IncRNAs may have a vital role in the process of regulating AM functions via regulating expression of target genes in the absence of commensal microbiota.

In this study, by using a mouse model treated with antibiotics, we first studied the regulatory role of IncRNAs on AM functions in the absence of commensal microbiota. The resulting data strongly link the commensal microbiota to AMs and IncRNA function. This enabled us to further investigate the specific molecular mechanism by which commensal microbiota regulate AM functions via IncRNAs. We found that IncRNA-30162 regulates the expression of CCL24 and ARG1 in macrophages. These data validate the importance of commensal microbiota for AM function, demonstrating that they have an essential role, and identify a new molecular mechanism by which IncRNA-30162 may regulate macrophage function.

\section{Methods}

Mice and antibiotic treatment 
Female C57BL/6 mice, 4- to 5-week-old, were acquired from the Shanghai Experimental Center of the Chinese Science Academy (Shanghai, China). As mentioned above [21], mice were treated with neomycin sulfate $(1 \mathrm{~g} / \mathrm{L})$, ampicillin $(1 \mathrm{~g} / \mathrm{L})$, vancomycin $(0.5 \mathrm{~g} / \mathrm{L})$, and metronidazole $(1 \mathrm{~g} / \mathrm{L})$ in their drinking water for 4- 6 weeks, which was replaced twice per week. Mice were anesthetized with isoflurane, their eyeball was removed for blooding, then the mice were killed by severing the spinal cords. Animal experiments were approved by the Animal Care and Use Local Ethics Committee. The procedure was carried out according to the Guide for the Care and Use of Laboratory Animals issued by Anhui Medical University.

Segregation of lung mononuclear cells

As mentioned above [22], by density gradient centrifugation, and using $40 \%$ and $70 \%$ Percoll solution, mononuclear cells were isolated from the lungs.

\section{Purification of AMs}

Segregated lung mononuclear cells were stained, subsequently, $\mathrm{AMs}\left(\mathrm{F} 4 / 80^{+} \mathrm{CD} 11 \mathrm{c}^{+}\right)$were sorted using a FACS Aria II flow cytometer (Becton Dickinson, Franklin Lakes, NJ, USA). The purity of separated cells was more than ninety-five percent.

Microarray analysis

Microarray analysis was conducted as previously described [12]. Microarray experiments were implemented by Shanghai Biotechnology Company (Shanghai, China). Principal component analysis was performed using ClustVis [23], with Pareto scaling applied to rows, and singular value decomposition with imputation was used for principal components calculation. Each sample was from sorted AMs from 15 mice.

GO and KEGG pathway analysis

The target genes of IncRNAs were predicted in trans and cis to reveal the potential function of IncRNAs. To predict cis roles (referring to the effect of IncRNAs on adjacent target genes) coding genes $10 \mathrm{~kb}$ downstream and upstream of the IncRNA were searched. For prediction of trans functions (referring to the impact of IncRNAs on the expression of other genes) GO and KEGG pathway analysis of target genes regulated by IncRNAs were performed as previously mentioned [24, 25]. By using R Bioconductor genomewide mouse annotations and the library GO stats 2.34.0 from the package org.Mm.eg.db (version 3.3.0), target genes (fold-change $\geq 2$ ) were converted to Entrez-IDs for GO and KEGG pathway analysis in $R$ 3.2.3. Results were sorted according to $p$-value $(p<0.05)$.

Quantitative Real-time PCR

Total RNA was extracted and purified using an miRNeasy Mini Kit (Cat. \#217004, Qiagen, GmBH, Germany). Reverse transcription reactions were performed in $80 \mu$ volumes: $5 \mu \mathrm{g}$ of total RNA, $8 \mu \mathrm{l} 5 \times$ buffer, $5 \mu \mathrm{mol} / \mathrm{L}$ oligo dT, $5 \mu \mathrm{mol} / \mathrm{L}$ random primers, $10 \mathrm{mmol} / \mathrm{L}$ DTT, $0.5 \mathrm{mmol} / \mathrm{L}$ dNTPs, 800 units of MMLV, 160 units of RNase inhibitor, and distilled water. Reverse transcription reactions were conducted at 
$25^{\circ} \mathrm{C}$ for $5 \mathrm{~min}, 37^{\circ} \mathrm{C}$ for $50 \mathrm{~min}$, heating at $70{ }^{\circ} \mathrm{C}$ for $15 \mathrm{~min}$. For PCR, $50 \mu$ l volume reactions contained $0.4 \mu \mathrm{mol} / \mathrm{L}$ forward and reverse primers, $25 \mu \mathrm{l} 2 \times$ PCR buffer, and $2 \mu \mathrm{l} \mathrm{cDNA}$ template. Quantitative realtime PCR was implemented using a Roche Light Cycler 480 II (Roche Diagnostics, Germany). PCR reactions were conducted using a total of 45 cycles, including a $25 \mathrm{sec}$ melting step at $95^{\circ} \mathrm{C}$, a $30 \mathrm{sec}$ annealing step at $60^{\circ} \mathrm{C}$, and $50 \mathrm{sec}$ of extension at $72{ }^{\circ} \mathrm{C}$. Information of the gene-specific primers is provided in Table 1. 
Table 1

The primers for each gene detected by real-time PCR

\begin{tabular}{|c|c|c|c|c|}
\hline Gene & Forward primer $\left(5^{\prime}-3^{\prime}\right)$ & Reverse primer $\left(5^{\prime}-3^{\prime}\right)$ & $\begin{array}{l}\text { Amplicon } \\
\text { length } \\
\text { (bp) }\end{array}$ & Ref \\
\hline $\begin{array}{l}\text { LncRNA- } \\
30691\end{array}$ & ТССТСТАССАСТСТСТGССТ & GGGTGGGAATGGAAGGAAGA & 282 & $\begin{array}{l}\text { This } \\
\text { work }\end{array}$ \\
\hline $\begin{array}{l}\text { LncRNA- } \\
2705\end{array}$ & CCTGGGTAGAGAGAGATGCG & GTAGCATGTCCAACAGCAGG & 191 & $\begin{array}{l}\text { This } \\
\text { work }\end{array}$ \\
\hline $\begin{array}{l}\text { LncRNA- } \\
73745\end{array}$ & TACACTGGTGCCTGCCTTTA & TGGTATCAGGGATGCTGCAT & 180 & $\begin{array}{l}\text { This } \\
\text { work }\end{array}$ \\
\hline $\begin{array}{l}\text { LncRNA- } \\
92004\end{array}$ & TTGGTGGCTTTCTGGATTGC & СTTCCCTGTTGTCCCTGGAT & 275 & $\begin{array}{l}\text { This } \\
\text { work }\end{array}$ \\
\hline $\begin{array}{l}\text { LncRNA- } \\
1605\end{array}$ & GCTCGCTCATCAAGAAACGT & СTTCCTGGTTCAAGCTCTGC & 257 & $\begin{array}{l}\text { This } \\
\text { work }\end{array}$ \\
\hline $\begin{array}{l}\text { LncRNA- } \\
13019\end{array}$ & TGCATCATCGACTCAGGGAA & АTCTCTGTCTCACCCACGAG & 168 & $\begin{array}{l}\text { This } \\
\text { work }\end{array}$ \\
\hline $\begin{array}{l}\text { LncRNA- } \\
65144\end{array}$ & TCTCTTTTCCCAAGGCCGAA & CATTCCCAAAGCTGAGCGAT & 208 & $\begin{array}{l}\text { This } \\
\text { work }\end{array}$ \\
\hline $\begin{array}{l}\text { LncRNA- } \\
87138\end{array}$ & AAGCCACCTACTACTGTGCA & TCTTCAGCGTATCCCCTTCC & 279 & $\begin{array}{l}\text { This } \\
\text { work }\end{array}$ \\
\hline $\begin{array}{l}\text { LncRNA- } \\
87135\end{array}$ & TGGGGAAAGAGCACAGTTGT & AGAGAAGCTGATGATGGCCA & 185 & $\begin{array}{l}\text { This } \\
\text { work }\end{array}$ \\
\hline $\begin{array}{l}\text { LncRNA- } \\
12429\end{array}$ & GCCAACAGATTCAGCTAGCC & TGTGAATCGCTGTCCTCCTT & 211 & $\begin{array}{l}\text { This } \\
\text { work }\end{array}$ \\
\hline $\begin{array}{l}\text { LncRNA- } \\
87049\end{array}$ & СCTGGCTGTTCCCCTATGAA & GCACGGAACATTTCACGGAT & 301 & $\begin{array}{l}\text { This } \\
\text { work }\end{array}$ \\
\hline $\begin{array}{l}\text { LncRNA- } \\
29008\end{array}$ & AAGTGGCTCTGTCTGGTCTC & CCCCATTGCTGTGCTGAAAT & 172 & $\begin{array}{l}\text { This } \\
\text { work }\end{array}$ \\
\hline $\begin{array}{l}\text { LncRNA- } \\
51618\end{array}$ & AGGAAGCCGAGGGAAAGAAA & GGGGAAAGAAGGAAAGGGGA & 165 & $\begin{array}{l}\text { This } \\
\text { work }\end{array}$ \\
\hline $\begin{array}{l}\text { LncRNA- } \\
54499\end{array}$ & GCATTTGTGAGCACTGACCA & TCCAGTGTTCCCAGATGTCC & 212 & $\begin{array}{l}\text { This } \\
\text { work }\end{array}$ \\
\hline $\begin{array}{l}\text { LncRNA- } \\
10921\end{array}$ & CTGGGCAGTAAAACGAACGT & GGGACCCAGCCATCATCTTA & 282 & $\begin{array}{l}\text { This } \\
\text { work }\end{array}$ \\
\hline $\begin{array}{l}\text { LncRNA- } \\
44232\end{array}$ & GGTCTCGTTTTCTGCTGTGG & GTTAGCCCTGGTGTCTTTGC & 248 & $\begin{array}{l}\text { This } \\
\text { work }\end{array}$ \\
\hline $\begin{array}{l}\text { LncRNA- } \\
35328\end{array}$ & GAGGCCAGGAAGAGGAGAAG & AATAAGCAGCCCACCAGACT & 323 & $\begin{array}{l}\text { This } \\
\text { work }\end{array}$ \\
\hline
\end{tabular}




\begin{tabular}{|c|c|c|c|c|}
\hline Gene & Forward primer $\left(5^{\prime}-3^{\prime}\right)$ & Reverse primer $\left(5^{\prime}-3^{\prime}\right)$ & $\begin{array}{l}\text { Amplicon } \\
\text { length } \\
\text { (bp) }\end{array}$ & Ref \\
\hline $\begin{array}{l}\text { LncRNA- } \\
75509\end{array}$ & TCTGTGCACGGCTCTATAGG & ATGAAGCCTTGGTGAGAGCA & 179 & $\begin{array}{l}\text { This } \\
\text { work }\end{array}$ \\
\hline $\begin{array}{l}\text { LncRNA- } \\
64449\end{array}$ & TCTTGATGAGCAGCTTGGGA & CAGGCTGTGATGGAAGATGC & 224 & $\begin{array}{l}\text { This } \\
\text { work }\end{array}$ \\
\hline $\begin{array}{l}\text { LncRNA- } \\
5252\end{array}$ & CGCTATGAGTCGTGTGTGTG & CCAGTGGAAGCAGAGACAGA & 175 & $\begin{array}{l}\text { This } \\
\text { work }\end{array}$ \\
\hline $\begin{array}{l}\text { LncRNA- } \\
58315\end{array}$ & TGGTTCAGTTCTCCAGCCAT & AGTTGCAATTGACAGCCCAG & 240 & $\begin{array}{l}\text { This } \\
\text { work }\end{array}$ \\
\hline $\begin{array}{l}\text { LncRNA- } \\
22486\end{array}$ & CCACCTGCTGCATTTGAGTT & TGCCACATAGATCCACTGGG & 285 & $\begin{array}{l}\text { This } \\
\text { work }\end{array}$ \\
\hline $\begin{array}{l}\text { LncRNA- } \\
73020\end{array}$ & TCAGAGGGCCCAGTTTCATT & CACACATGCACCTACAGTCG & 294 & $\begin{array}{l}\text { This } \\
\text { work }\end{array}$ \\
\hline $\begin{array}{l}\text { LncRNA- } \\
74533\end{array}$ & TGCATTATGTGAGCCTCCCA & AAGGCCTCCATGATTCACCA & 211 & $\begin{array}{l}\text { This } \\
\text { work }\end{array}$ \\
\hline $\begin{array}{l}\text { LncRNA- } \\
22855\end{array}$ & AAGGGATGTGTGCAGCTTTG & TGATTACTGGAGTGGCTGCT & 157 & $\begin{array}{l}\text { This } \\
\text { work }\end{array}$ \\
\hline $\begin{array}{l}\text { LncRNA- } \\
78402\end{array}$ & AGACCTACATTGAGCCCACC & GGGTAGCAGAGTGTGGATGT & 244 & $\begin{array}{l}\text { This } \\
\text { work }\end{array}$ \\
\hline $\begin{array}{l}\text { LncRNA- } \\
42066\end{array}$ & GTGTGCCCTTCATCTCGTTC & AAGAGTGGTAGGGAAAGGGC & 288 & $\begin{array}{l}\text { This } \\
\text { work }\end{array}$ \\
\hline $\begin{array}{l}\text { LncRNA- } \\
30162\end{array}$ & TATTTCACCAAGCACCGCAC & TGCTGACACATAACGTTGCA & 275 & $\begin{array}{l}\text { This } \\
\text { work }\end{array}$ \\
\hline $\begin{array}{l}\text { LncRNA- } \\
4821\end{array}$ & GAAACTTCCGTGTCCTGTAGG & GAGACTGTGAGCCTGACTGA & 194 & $\begin{array}{l}\text { This } \\
\text { work }\end{array}$ \\
\hline CCL24 & СTCCTTCTCCTGGTAGCCTG & ATGGCCCTTCTTGGTGATGA & 183 & [12] \\
\hline Arg1 & GCTGGGAAGGAAGAAAAGGC & TGCCGTGTTCACAGTACTCT & 232 & [12] \\
\hline IGF1 & ACTGGAGATGTACTGTGCCC & CAAAGGATCCTGCGGTGATG & 253 & [12] \\
\hline RBP4 & TTCTGTGGACGAGAAGGGTC & GTGCCATCCAGATTCTGCAG & 249 & [12] \\
\hline Timp1 & TATGCCCACAAGTCCCAGAA & АСTCTCCAGTTTGCAAGGGA & 210 & [12] \\
\hline$\beta$-actin & TGACGTTGACATCCGTAAAGACC & CTCAGGAGGAGCAATGATCTTGA & 148 & [33] \\
\hline GAPDH & TGCACCACCAACTGCTTAG & GGATGCAGGGATGATGTTC & 177 & [34] \\
\hline
\end{tabular}

FISH analysis 
For FISH assays, fluorescence-conjugated IncRNA30162 probes were acquired from Shanghai Gene Pharma Co. Ltd. (Shanghai, China). RAW264.7 macrophages were acquired from the Shanghai Cell Bank of Chinese Academy of Sciences (Shanghai, China), and were treated in nondenaturing conditions, followed by hybridization with IncRNA 30162 probes. The slide was hybridized at $37^{\circ} \mathrm{C}$ for $16 \mathrm{~h}$. After RNA hybridization, samples were incubated in 4',6-diamidino-2-phenylindole (1:1000) for 5 min of counterstaining, and observed by confocal microscopy (TCS SP5, Leica).

RNA interference

RAW264.7 cells $\left(1 \times 10^{5}\right)$ were plated in 6-well plates and transfected with small interfering RNA (siRNA), including si-NC, si-GAPDH, and si-IncRNA30162 sequences, using Lipofectamine 2000 (Invitrogen, Carlsbad, CA, USA). The siRNA sequences were provided in Table 2. After $48 \mathrm{~h}$, cells were harvested for total RNA extraction. Knockdown efficiency was assessed using RT-qPCR. All siRNA sequences were supplied by Shanghai GenePharma Company (Shanghai, China).

Table 2

The siRNA sequences for RNA interference

\begin{tabular}{|lll|}
\hline Gene & sense $\left(\mathbf{5}^{\prime} \mathbf{3}^{\prime} \mathbf{3}^{\prime}\right)$ & antisense $\mathbf{( 5}^{\prime} \mathbf{3}^{\prime} \mathbf{)}$ \\
\hline silncRNA-30162 & GCCGUGAAUUAUCUAACAATT & UUGUUAGAUAAUUCACGGCTT \\
\hline siGAPDH & CACUCAAGAUUGUCAGCAATT & UUGCUGACAAUCUUGAGUGAG \\
\hline siNC & UUCUCCGAACGUGUCACGUTT & ACGUGACACGUUCGGAGAATT \\
\hline
\end{tabular}

\section{ELISA}

Culture supernatants from RAW264.7 cells were collected and centrifuged to remove cellular debris. ELISAs for detection of ARG1 (KB13668, Shanghai Jiang Lai Biotechnology Co., China) and CCL24 (ab100681, Abcam, UK) were conducted following the manufacturer's instructions.

\section{Results}

Treatment with antibiotics resulted in differential expression of numerous IncRNAs in alveolar macrophages

AMs $\left(\mathrm{F} 4 / 80^{\square} \mathrm{CD} 11^{\square}\right)$ from Abt (C57BL/ 6 females were provided with a compound of four antibiotics in their drinking water) and control group (C57BL/ 6 mice, female, 10W, SPF) mice were purified from lung MNCs by FACS. Purified AMs were acquired for IncRNA analysis (Fig. 1A). The expression profiles of all detected IncRNAs are presented in Fig. 1B as volcano plots. Clustering analysis of differentially expressed IncRNAs was conducted to aid determination of the functions of both unknown and known IncRNAs (Fig. 1C). Compared with controls, there were 363 up-regulated IncRNAs (57.26\%) and 271 down-regulated IncRNAs $(42.74 \%)$ in the Abt group, with a total of 634 IncRNAs exhibiting $\geq 2$ fold-change (Fig. 1D). Hence, antibiotic treatment led to differential expression of numerous IncRNAs in AMs. 
Further, GO and KEGG pathway analyses were applied to determine the possible biological functions of the predicted target genes of IncRNAs differentially expressed in AMs from Abt mice. Functional analysis of IncRNAs target genes was performed to search for related GO terms and pathways in both cis and trans (Fig. 2). Identifying cis target genes was based on the principle that the IncRNAs are close to protein-coding genes they regulated in cis. Target genes of differentially expressed IncRNAs in cis are presented in Fig. 2A. The rational for identifying trans target genes was that the functions of IncRNAs can be recognized by coexpression with protein-coding genes they regulated in trans. Target genes regulated by IncRNAs in trans are presented in Fig. 2B. These results indicate that IncRNA target genes were associated with several biological pathways, including regulation of immune system processes, angiogenesis, cell differentiation, and chemotaxis, among others.

LncRNA-30162 expression was up-regulated in AMs from Abt mice

To confirm the results of the microarray analysis, 29 IncRNAs were randomly selected for RT-qPCR verification, including 17 that were up-regulated and 12 that were down-regulated, based on microarray data. All 29 IncRNA RT-qPCR validation assays generated similar fold-change results to those determined by microarray, indicating that the data acquired using gene chips were highly reliable. Among the analyzed genes, the expression levels of IncRNA-30162 were up-regulated in AMs from Abt mice (Fig. 3A, B).

In addition, the RT-qPCR analysis showed that there was no remarkable difference in IncRNA-30162 expression between AMs and the mouse macrophage cell line, RAW264.7 (Fig. 4A). Next, we determined the subcellular localization of IncRNA-30162 in RAW264.7 cells. FISH assays using a specific probe confirmed that IncRNA-30162 was mainly distributed in the cytoplasm of RAW264.7 macrophages (Fig. 4B).

Knockdown of IncRNA-30162 expression levels in RAW264.7 cells significantly reduced levels of CCL24 and ARG1

As we reported previously, commensal microbiota maintain low level CCL24 production by AMS, mediating anti-metastatic tumor activity [12]. Based on our findings of differential expression of IncRNAs in AMs from Abt mice, and upregulation of IncRNA-30162 expression in AMs from Abt mice compared with those from untreated counterparts, we next investigated whether IncRNA-30162 is involved in the expression of immune-related genes in AMs. RAW264.7 cells were used as an alternative to AMs, and IncRNA-30162 knockdown was performed by transfecting siRNA into RAW264.7 cells. Knockdown efficiency (Fig. 5A) and the expression of related genes were evaluated by RT-qPCR. The results indicated that Ccl24 and Arg1 were down-regulated following IncRNA-30162 knockdown, while levels of Timp1, Igf1, and Mmp12 did not differ obviously (Fig. 5B). These findings were confirmed by ELISA (Fig. 5C, D). Overall, these results indicate that IncRNA-30162 knockdown can down-regulate the expression of CCL24 and ARG1 in RAW264.7 cells.

\section{Discussion}


Despite recent progress in understanding the effects of commensal microbiota on AMs [12], the molecular mechanisms by which these effects are exerted remain poorly understood. In this study, gene analysis of AMs from Abt mice was performed, and 634 IncRNAs were identified as differentially expressed in response to antibiotic treatment, including 363 up-regulated and 271 down-regulated IncRNAs (Fig. 1). Furthermore, according to GO and KEGG pathway analysis, target genes of IncRNAs were associated with regulation of immune system, angiogenesis, chemotaxis, and cell differentiation, among other functions (Fig. 2). One of these IncRNAs, IncRNA-30162, was markedly up-regulated by antibiotic treatment. In RAW264.7 cells, IncRNA-30162 expression levels did not differ significantly from that in AMs, and these findings were confirmed by RT-qPCR (Fig. 4A). Overall, our results show that the absence of commensal microbiota results in differential expression of IncRNAs in AMs, and several IncRNAs are reportedly involved in the regulation of macrophages [26-29]. Further investigation revealed that IncRNA-30162 knockdown can significantly reduce the expression levels of CCL24 and ARG1 in RAW264.7 macrophages. Thus, our study demonstrates a novel role for IncRNA-30162 in macrophage regulation.

Commensal microbiota have important roles in promoting clearance of bacteria from the lung, and microbiome induce AMs to produce antibacterial activity via the ERK pathway. [10]. Recently, several IncRNAs have been implicated in regulation of immunity and inflammation through their influence on macrophages, including IncRNA E33, IncRNA Malat2, and IncRNA-CCL2 [17-19]. RAW264.7 cells treated with high glucose and free fatty acids led to increased expression of IncRNA uc.48\ and induced inflammatory and P2 × 7R-mediated immune responses via ROS formation, cytokine secretion, and activation of the ERK signaling pathway [30]; however, to date, there has been no report regarding the relationship among commensal microbiota, IncRNAs, and AM function. In this study, we sought to investigate IncRNAs regulated by commensal microbiota in AMs, and identify those IncRNAs that may participate in regulating macrophage functions. We identified IncRNA-30162 as a potent regulator of macrophages.

Our data also show that IncRNA-30162 knockdown altered the expression level of CCL24 and ARG1 in macrophages. High expression of CCL24 are strongly related to liver metastatic tumors and primary colorectal [31]. Further, low levels of CCL24, derived from AMs, are essential for natural anti-tumor responses in the lung [12]. ARG1 is induced in alternatively activated macrophages (M2), and is involved in tumor immunity, anti-inflammation, and immunosuppression-related diseases [32]. Hence, our data reveal crosstalk between commensal microbiota signaling and macrophages via IncRNA-30162. This may explain why AMs from Abt mice predominantly exhibit M2 activity, like higher expression of CCL24 and ARG1 [12]. Therefore, it is possible that commensal microbiota maintain AM production of low levels of CCL24 and ARG1 by regulating IncRNA-30162; however, further detailed RNA interference experiments using AMs will be required to determine whether IncRNA-30162 participates in regulation of AM function in the absence of commensal microbiota.

In summary, this study provides novel insights into the effects of commensal microbiota on IncRNA expression in AMs. Moreover, we have identified a signaling axis, comprising commensal microbiotaIncRNA30162- CCL24 and ARG1, with a crucial role in regulating immunity and inflammation. Our findings 
will assist further exploration of the mechanisms by which commensal microbiota regulate IncRNA expression in AMs.

\section{Abbreviations}

AMs

Alveolar macrophages

LncRNA

long non-coding RNA

Abt

antibiotic-treated

GF

germ-free

SPF

specific-pathogen-free (SPF)

FITC

fluorescein isothiocyanate

SiRNA

small interfering RNA

\section{Declarations}

\section{Ethics approval and consent to participate}

The study was approved by the Local Ethics Committee for Animal Care and Use at Anhui Medical University and were conducted in accordance with the Guide for the Care and Use of Laboratory Animals granted by Anhui Medical University.

\section{Consent for publication}

Not applicable

\section{Availability of data and materials}

The datasets used and/or analyzed during the current study are available from the corresponding author on reasonable request.

\section{Competing interests}

The authors have declared no conflict of interests.

\section{Finding}


This research was funded by the National Natural Science Foundation of China (81471552), the Anhui Provincial Project of the Key Laboratory of Tumor Immunotherapy and Nutrition Therapy (2018080503B0031).

\section{Authors contribution}

YJM performed all the experiments, analyzed data and prepared the manuscript; WC performed the RT-PCR experiments; SLH offered the financial support and supervised the study; MC designed all the experiments, prepared and revised the manuscript.

\section{Acknowledgements}

Not Applicable

\section{Author information}

\section{Affiliations}

Gerontology Institute of Anhui Province, Anhui Province Hospital, Anhui Medical University, Hefei, 230001, China;

Anhui Provincial Key Laboratory of Tumor Immunotherapy and Nutrition Therapy, Hefei, 230001, China;

Yingjie Mu, Wen Chen, Shilian Hu \& Min Cheng

\section{Corresponding author}

Correspondence to Shilian Hu.

\section{References}

1. Man WH, de Steenhuijsen Piters WA, Bogaert D. The microbiota of the respiratory tract: gatekeeper to respiratory health. Nature reviews Microbiology. 2017;15(5):259-70. doi:10.1038/nrmicro.2017.14.

2. Feng ZH, Li Q, Liu SR, Du XN, Wang C, Nie XH et al. Comparison of Composition and Diversity of Bacterial Microbiome in Human Upper and Lower Respiratory Tract. Chin Med J (Engl). 2017;130(9):1122-4. doi:10.4103/0366-6999.204934.

3. Segal LN, Alekseyenko AV, Clemente JC, Kulkarni R, Wu B, Gao Z et al. Enrichment of lung microbiome with supraglottic taxa is associated with increased pulmonary inflammation. Microbiome. 2013;1(1):19. doi:10.1186/2049-2618-1-19.

4. Dang AT, Marsland BJ. Microbes, metabolites, and the gut-lung axis. Mucosal Immunol. 2019;12(4):843-50. doi:10.1038/s41385-019-0160-6.

5. Li XV, Leonardi I, Iliev ID. Gut Mycobiota in Immunity and Inflammatory Disease. Immunity. 2019;50(6):1365-79. doi:10.1016/j.immuni.2019.05.023. 
6. Joshi N, Walter JM, Misharin AV. Alveolar Macrophages. Cell Immunol. 2018;330:86-90. doi:10.1016/j.cellimm.2018.01.005.

7. Hussell T, Bell TJ. Alveolar macrophages: plasticity in a tissue-specific context. Nat Rev Immunol. 2014;14(2):81-93. doi:10.1038/nri3600.

8. Byrne AJ, Mathie SA, Gregory LG, Lloyd CM. Pulmonary macrophages: key players in the innate defence of the airways. Thorax. 2015;70(12):1189-96. doi:10.1136/thoraxjnl-2015-207020.

9. Clarke TB. Early innate immunity to bacterial infection in the lung is regulated systemically by the commensal microbiota via nod-like receptor ligands. Infect Immun. 2014;82(11):4596-606. doi:10.1128/IAI.02212-14.

10. Brown RL, Sequeira RP, Clarke TB. The microbiota protects against respiratory infection via GM-CSF signaling. Nat Commun. 2017;8(1):1512. doi:10.1038/s41467-017-01803-x.

11. Prakash A, Sundar SV, Zhu YG, Tran A, Lee JW, Lowell C et al. Lung Ischemia-Reperfusion is a Sterile Inflammatory Process Influenced by Commensal Microbiota in Mice. Shock. 2015;44(3):272-9. doi:10.1097/SHK.0000000000000415.

12. Cheng $M$, Chen $Y$, Wang $L$, Chen $W$, Yang $L$, Shen $G$ et al. Commensal microbiota maintains alveolar macrophages with a low level of CCL24 production to generate anti-metastatic tumor activity. Sci Rep. 2017;7(1):7471. doi:10.1038/s41598-017-08264-8.

13. Peng WX, Koirala P, Mo YY. LncRNA-mediated regulation of cell signaling in cancer. Oncogene. 2017;36(41):5661-7. doi:10.1038/onc.2017.184.

14. Tam C, Wong JH, Tsui SKW, Zuo T, Chan TF, Ng TB. LncRNAs with miRNAs in regulation of gastric, liver, and colorectal cancers: updates in recent years. Appl Microbiol Biotechnol. 2019;103(12):464977. doi:10.1007/s00253-019-09837-5.

15. Liang L, Ai L, Qian J, Fang JY, Xu J. Long noncoding RNA expression profiles in gut tissues constitute molecular signatures that reflect the types of microbes. Sci Rep. 2015;5:11763. doi:10.1038/srep11763.

16. Dempsey J, Zhang A, Cui JY. Coordinate regulation of long non-coding RNAs and protein-coding genes in germ-free mice. BMC Genomics. 2018;19(1):834. doi:10.1186/s12864-018-5235-3.

17. Reddy MA, Chen Z, Park JT, Wang M, Lanting L, Zhang Q et al. Regulation of inflammatory phenotype in macrophages by a diabetes-induced long noncoding RNA. Diabetes. 2014;63(12):4249-61. doi:10.2337/db14-0298.

18. Du M, Yuan L, Tan X, Huang D, Wang X, Zheng Z et al. The LPS-inducible IncRNA Mirt2 is a negative regulator of inflammation. Nat Commun. 2017;8(1):2049. doi:10.1038/s41467-017-02229-1.

19. Jia Y, Li Z, Cai W, Xiao D, Han S, Han F et al. SIRT1 regulates inflammation response of macrophages in sepsis mediated by long noncoding RNA. Biochim Biophys Acta Mol Basis Dis. 2018;1864(3):78492. doi:10.1016/j.bbadis.2017.12.029.

20. Cui H, Banerjee S, Guo S, Xie N, Ge J, Jiang D et al. Long noncoding RNA Malat1 regulates differential activation of macrophages and response to lung injury. JCI Insight. 2019;4(4).

doi:10.1172/jci.insight.124522.

Page $13 / 19$ 
21. Cheng M, Qian L, Shen G, Bian G, Xu T, Xu W et al. Microbiota modulate tumoral immune surveillance in lung through a gammadeltaT17 immune cell-dependent mechanism. Cancer Res. 2014;74(15):4030-41. doi:10.1158/0008-5472.CAN-13-2462.

22. Wang J, Li F, Zheng M, Sun R, Wei $H$, Tian Z. Lung natural killer cells in mice: phenotype and response to respiratory infection. Immunology. 2012;137(1):37-47. doi:10.1111/j.1365-2567.2012.03607.x.

23. Metsalu T, Vilo J. ClustVis: a web tool for visualizing clustering of multivariate data using Principal Component Analysis and heatmap. Nucleic Acids Res. 2015;43(W1):W566-70. doi:10.1093/nar/gkv468.

24. Ashburner M, Ball CA, Blake JA, Botstein D, Butler H, Cherry JM et al. Gene ontology: tool for the unification of biology. The Gene Ontology Consortium. Nat Genet. 2000;25(1):25-9. doi:10.1038/75556.

25. Kanehisa M, Goto S. KEGG: kyoto encyclopedia of genes and genomes. Nucleic Acids Res. 2000;28(1):27-30. doi:10.1093/nar/28.1.27.

26. Li Z, Feng C, Guo J, Hu X, Xie D. GNAS-AS1/miR-4319/NECAB3 axis promotes migration and invasion of non-small cell lung cancer cells by altering macrophage polarization. Funct Integr Genomics. 2019. doi:10.1007/s10142-019-00696-x.

27. Li N, Liu Y, Cai J. LncRNA MIR155HG regulates M1/M2 macrophage polarization in chronic obstructive pulmonary disease. Biomed Pharmacother. 2019;117:109015. doi:10.1016/j.biopha.2019.109015.

28. Zhang $P$, Cao L, Zhou R, Yang X, Wu M. The IncRNA Neat1 promotes activation of inflammasomes in macrophages. Nat Commun. 2019;10(1):1495. doi:10.1038/s41467-019-09482-6.

29. Wang Y, Luo Y, Yao Y, Ji Y, Feng L, Du F et al. Silencing the IncRNA Maclpil in pro-inflammatory macrophages attenuates acute experimental ischemic stroke via LCP1 in mice. J Cereb Blood Flow Metab. 2019:271678X19836118. doi:10.1177/0271678X19836118.

30. Wu H, Wen F, Jiang M, Liu Q, Nie Y. LncRNA uc.48+ is involved in the diabetic immune and inflammatory responses mediated by P2X7 receptor in RAW264.7 macrophages. Int J Mol Med. 2018;42(2):1152-60. doi:10.3892/ijmm.2018.3661.

31. Cheadle EJ, Riyad K, Subar D, Rothwell DG, Ashton G, Batha H et al. Eotaxin-2 and colorectal cancer: a potential target for immune therapy. Clin Cancer Res. 2007;13(19):5719-28. doi:10.1158/10780432.CCR-07-1145.

32. You J, Chen W, Chen J, Zheng Q, Dong J, Zhu Y. The Oncogenic Role of ARG1 in Progression and Metastasis of Hepatocellular Carcinoma. Biomed Res Int. 2018;2018:2109865. doi:10.1155/2018/2109865.

33. Mathew R, Futterweit S, Valderrama E, Tarectecan AA, Bylander JE, Bond JS et al. Meprin-alpha in chronic diabetic nephropathy: interaction with the renin-angiotensin axis. Am J Physiol Renal Physiol. 2005;289(4):F911-21. doi:00037.2005 [pii\}10.1152/ajprenal.00037.2005.

34. Yonezawa T, Chen KH, Ghosh MK, Rivera L, Dill R, Ma L et al. Anti-metastatic outcome of isoformspecific prolactin receptor targeting in breast cancer. Cancer Lett. 2015;366(1):84-92. doi:10.1016/j.canlet.2015.06.010. 


\section{Figures}

Fig1
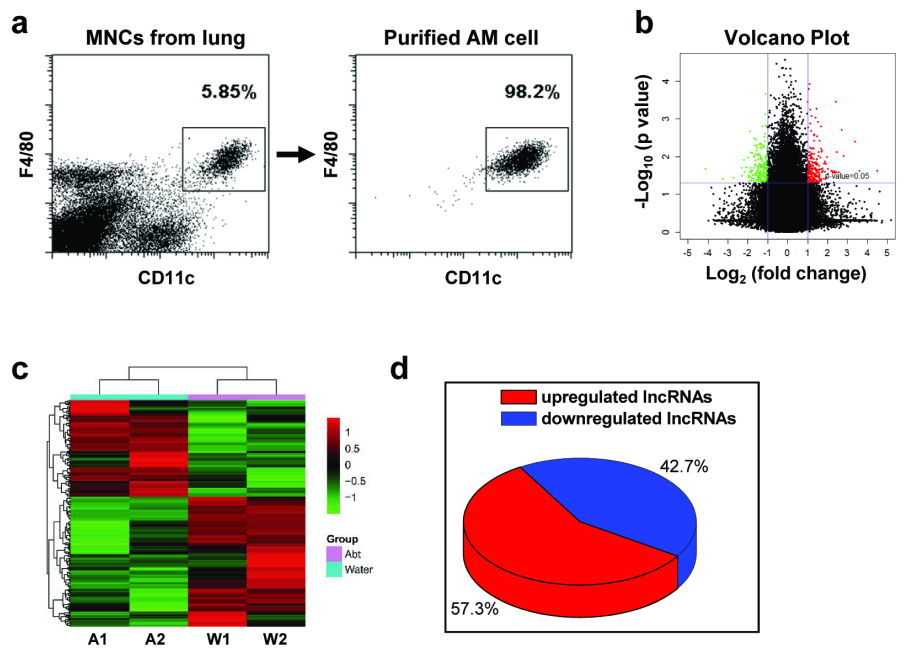

\section{Figure 1}

There are numerous differentially expressed IncRNAs in AMs from Abt mice. a Detection of AMs (F4/80区

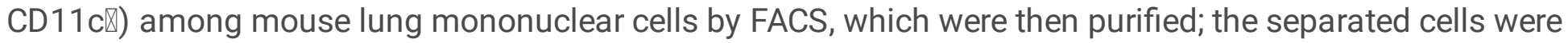
$>95 \%$ pure. b Volcano plots of differentially expressed IncRNAs. The green and red dots represent significant down-regulated and up-regulated IncRNAs (fold-change $\geq 2$ and $P<0.05$ ). c Hierarchical cluster heat map indicating IncRNA expression profiles. Black signal refers to no change, the red indicates high relative expression, and green indicates low relative expression. $d$ The pie chart shows the distribution of the differentially expressed IncRNAs in the Abt group (15 mice per sample, 2 samples per group). 
Fig2

a
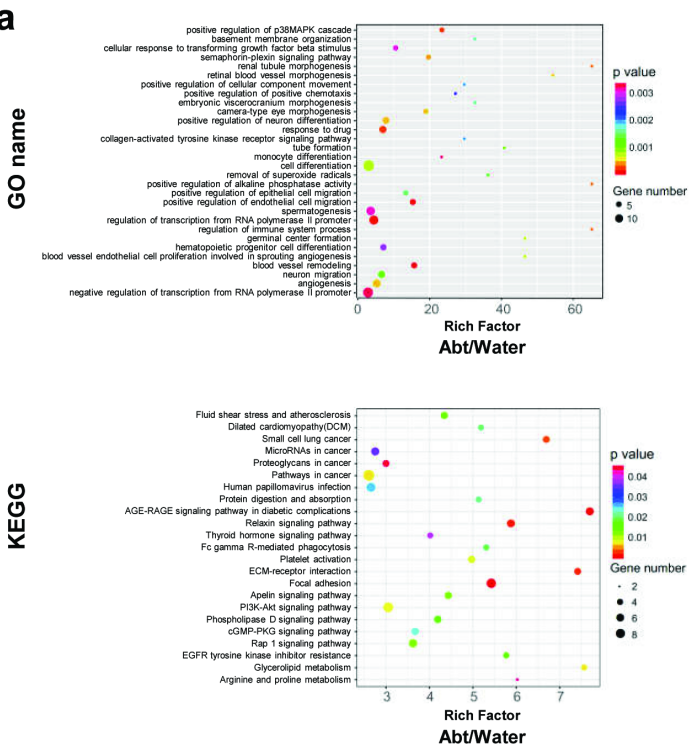

b
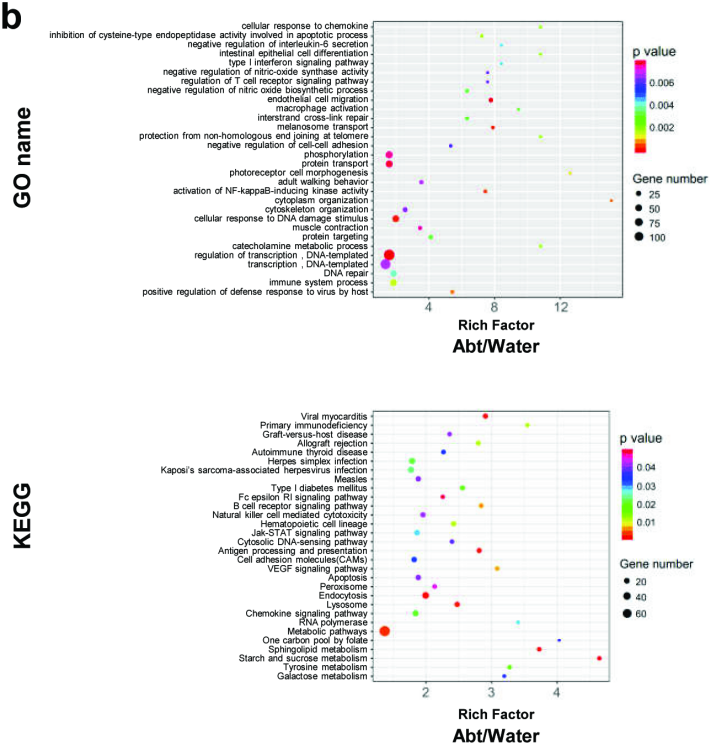

\section{Figure 2}

Prediction and functional analysis of IncRNAs target genes in Abt and control mice. In the Abt group, mice were treated with mixed antibiotics for 5 weeks. GO and KEGG enrichment scatter plots for cis a and trans b of IncRNAs target genes. 
Fig3
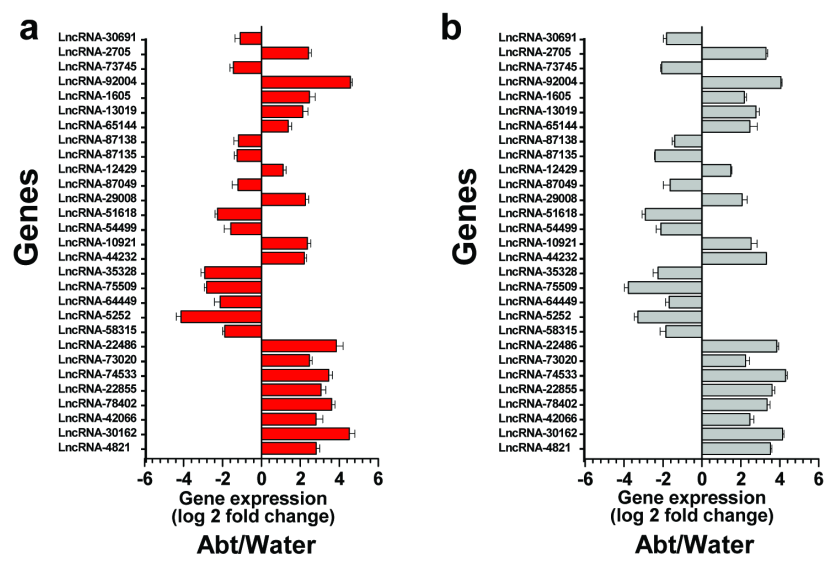

\section{Figure 3}

RT-qPCR validation of 29 randomly selected IncRNAs. a The 29 differentially expressed IncRNAs were randomly selected ( 17 were up-regulated and 12 were down-regulated). b 29 IncRNAs validated by RT-qPCR showed similar fold-change values as those determined by microarray. 


\section{Fig4}

a

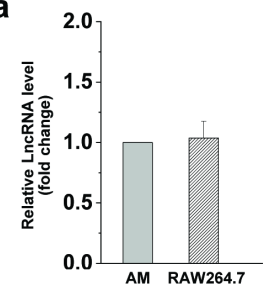

b

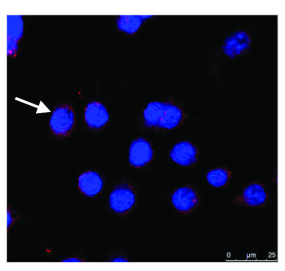

\section{Figure 4}

LncRNA-30162 was predominantly distributed in the cytoplasm of RAW264.7 cells. a RT-qPCR analysis of IncRNA-30162 expression in RAW264.7 cells (mouse macrophage cell line) and AMs. b Fluorescence in situ hybridization (FISH) showing the subcellular location of IncRNA-30162, determined using a specific probe in RAW264.7 cells. The arrows indicate that IncRNA-30162 was predominantly distributed in the cytoplasm. 
Fig5
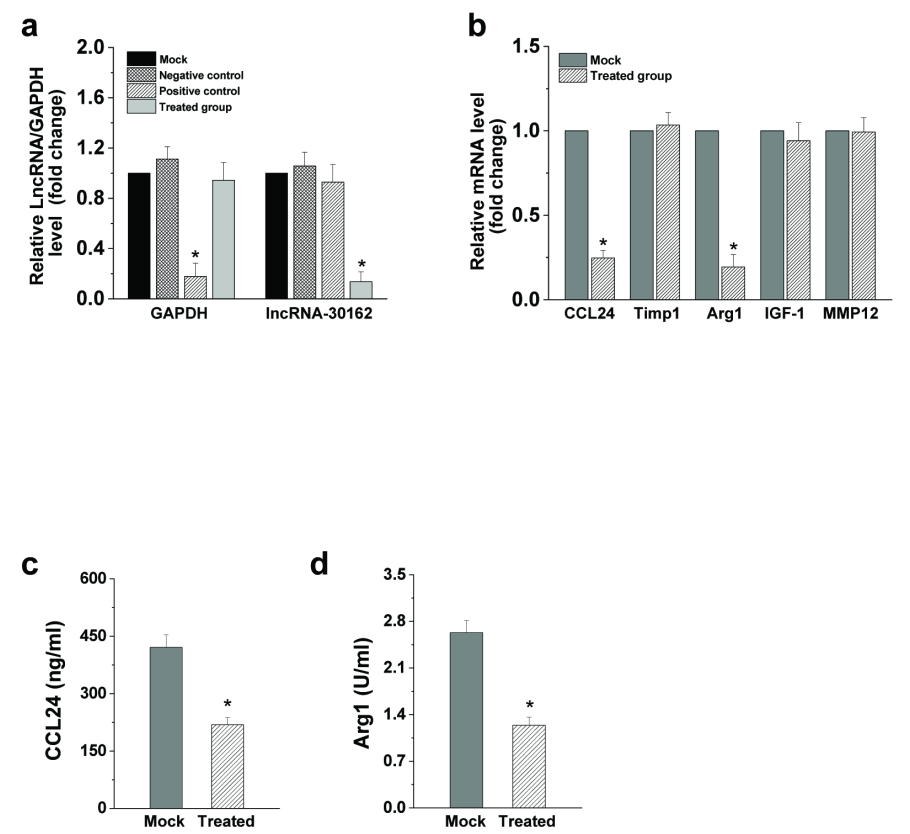

\section{Figure 5}

Knockdown of IncRNA-30162 expression levels in RAW264.7 macrophages significantly reduced levels of CCL24 and ARG1. a siRNA silencing effects were evaluated by RT-qPCR; ${ }^{*} P<0.05, * \star P<0.01, * \star \star P<0.001$, compared with Gapdh. b RT-qPCR analysis of relative mRNA levels in RAW264.7 macrophages treated with siRNA targeting IncRNA-30162. c, d ELISA analysis of CCL24 and ARG1 expression levels in RAW264.7 macrophages; $* \mathrm{P}<0.05$.

\section{Supplementary Files}

This is a list of supplementary files associated with this preprint. Click to download.

- ARRIVEGuidelinesChecklist.pdf 